\title{
Pengaruh Penerapan Model Pembelajaran Quantum Teachingterhadap Pemahaman Konsep Matematis Berdasarkan Minat Belajar Matematika Siswa Sekolah Menengah Pertama Kampar
}

\author{
Ratna Sari ${ }^{1}$, Suhandri ${ }^{2}$ dan Hayatun Nufus ${ }^{3}$ \\ ${ }^{12}$ Program studi pendidikean matematika, Universitas Islam Negeri Sultan Syarif Kasim Riau \\ e-mail: hayatun.nufus@uin-suska.ac.id
}

\begin{abstract}
ABSTRAK
Penelitian ini bertujuan untuk mengetahui ada atau tidaknya pengaruh penerapan model pembelajaran Quantum Teaching terhadap pemahaman konsep matematis berdasarkan minat belajar matematika siswa Sekolah Menengah Pertama Kampar. Penelitian ini merupakan penelitian quasy eksperimen dengan desain penelitian the nonequivalent pretest-posttes control group design.Populasi penelitian ini adalah siswa Sekolah Menengah Pertama Kampar. Sampel penelitian ini dipilih dengan menggunakan teknik porposive sampling, terpilih kelas VIII-5 sebagai kelas eksperimen, dan kelas VIII-6 sebagai kelas kontrol di Sekolah Menengah Pertama Negeri 2 Bangkinang Kota.Teknik pengumpulan data yang digunakan adalah teknik tes, teknik angket dan teknik observasi. Instrumen yang digunakan adalah tes uraian untuk mengukur kemampuan pemahaman konsep matematis siswa, angket untuk mengukur minat belajar matematika siswa, dan lembar observasi berupa lembar observasi aktivitas guru dan siswa untuk menentukan "ada atau tidak adanya" kegiatankegiatan yang harus dilaksanakan selama proses pembelajaran berlangsung dengan menerapkan model pembelajaran Quantum Teaching.Teknik analisis data yang digunakan dalam penelitian ini adalah uji-t untuk mengetahui kemampuan pemahaman kosep matematis siswa. Berdasarkan hasil analisis data dapat disimpulkan bahwa terdapat perbedaan kemampuan pemahaman konsep matematis antara siswa yang mengikuti pembelajaran dengan model Quantum Teaching dengan siswa yang mengikuti pembelajaran yang diterapkan guru dan terdapat perbedaan kemampuan pemahaman konsep matematis antara siswa berminat belajar tinggi, sedang dan rendah yang belajar mengikuti pembelajaran dengan model Quantum Teaching dengan siswa berminat belajar tinggi, sedang dan rendah yang belajar mengikuti pembelajaran yang diterapkan guru.
\end{abstract}

Kata Kunci: Quantum Teaching, Kemampuan Pemahaman Konsep Matematis, Minat Belajar.

\section{PENDAHULUAN}

Dalam Peraturan Mentri Pendidikan dan Kebudayaan Nomor 58 Tahun 2014 tentang kurikulum SMP dijelaskan bahwa pelajaran matematika bertujuan agar peserta didik mendapatkan beberapa hal sebagai berikut:(1) Memahami konsep matematika, menjelaskan keterkaitan antara konsep dan mengaplikasikan konsep atau algoritma secara luwes, akurat, efesien dan tepat dalam pemecahan masalah (2) Menggunakan pola sebagai dugaan dalam penyelesaian masalah, dan mampu membuat generalisasi berdasarkan fenomena atau data yang ada. (3) Menggunakan penalaran pada sifat, melakukan manipulasi matematika baik dalam penyederhanaan maupun menganalisa komponen yang ada dalam pemecahan masalah dalam konteks matematika maupun di luar matematika. (4) Mengkomunikasikan gagasan, penalaran, serta, mampu menyusun bukti matematika dengan menggunakan kalimat lengkap, simbol, tabel, diagram,ataupun media lain 
untuk memperjelas keadaan atau masalah. (5) Memiliki sikap menghargai kegunaan matematika dalam kehidupan, yaitu memiliki rasa ingin tahu, perhatian dan minat dalam mempelajari matematika, serta sikap ulet dan pecaya diri dalam pemecahan masalah. (6) Memiliki sikap dan perilaku yang sesuai dengan nilai-nilai dalam matematika dan pembelajarannya, seperti taat azaz, konsisten, menjunjung tinggi kesepakatan, toleran, menghargai pendapat orang lain, santun, demokrasi, ulet, tangguh, kreatif, menghargai kesemestaan (konteks, lingkungan), kerja sama, adil, jujur, teliti, cermat, bersikap luwes dan terbuka, memiliki kemauan berbagi rasa dengan orang lain.(7) Melakukan kegiatan-kegiatan motorik yang menggunakan pengetahuan matematika. (8) Menggunakan alat peraga sederhana maupun hasil teknologi untuk melakukan kegiatan-kegiatan matematika.

Tujuan pembelajaran matematika meliputi 5 aspek, yaitu: 1) pemahaman konsep, 2) pemecahan masalah, 3) penalaran, 4) komunikasi, dan 5) koneksi (Rozi Fitria, 2009:7). Berdasarkan tujuan pembelajaran matematika dalam Peraturan Mentri Pendidikan dan Kebudayaan Nomor 58 Tahun 2014 tentang kurikulum SMP dan tujuan pembelajaran menurut Rozi Fitria, jelas bahwa siswa harus memiliki kemampuan pemahaman konsep matematis. Kemampuan pemahaman konsep matematis adalah kemampuan yang sangat penting dan harus dimiliki dalam pembelajaran matematika.

Pemahaman konsep matematis juga merupakan salah satu tujuan dari setiap materi yang disampaikan oleh guru, sebab guru merupakan pembimbing siswa untuk mencapai konsep yang diharapkan (Heris hendriana, Euis Eti Rohaeti, Utari Sumarmo, 2017: 3). Berdasarkan hasil survei TIMSS menunjukkan bahwa matematika masih sangat jauh dari rata-rata internasional, dimana hasil survei TIMSS tahun 2011 Indonesia berada pada peringkat ke-38 dari 45 negara. Berdasarkan hasil yang diperoleh tersebut menunjukkan rendahnya hasil belajar matematika siswa SMP di Indonesia.

Untuk lebih membuktikan, peneliti melakukan wawancara di SMP Negeri 2 Bangkinang Kota dengan guru bidang studi matematika yaitu Ibuk Hj. Salniti, S.Pd. Berdasarkan hasil wawancara tersebut, diperoleh bahwa proses pembelajaran masih menunjukkan terdapat permasalahan pada kemampuan pemahaman konsep siswa yaitu masih banyaknya siswa yang memiliki pemahaman konsep matematika yang masih rendah. Peneliti juga mengadakan tes kemampuan pemahaman konsep matematis pada kelas VIII SMP Negeri 2 Bangkinang Kota. Dari hasil uji tes pemahaman konsep tersebut terlihat bahwa siswa belum mampu menyelesaikan soal kemampuan pemahaman konsep matematis. Hasil wawancara dengan ibuk Hj. Salniti, S.Pd beliau juga mengatakan bahwa beliau sudah berusaha mengajar dengan baik, memberikan tugas, bahkan melakukan proses pembelajaran dengan cara belajar berkelompok. Namun pada saat pemberian tugas kebanyakan siswa hanya menyalin jawaban dari teman yang lain dan siswa tidak mampu menyelesaikan soal yang berbeda dari contoh yang telah diberikan. Bahkan untuk sistem belajar kelompok yang telah dibuat masih kurang efektif karena tidak semua siswa aktif ataupun terlibat dalam kelompok. Pada saat mengerjakan soal yang diberikan guru ke setiap kelompok, siswa hanya menyalin jawaban dari teman sekelompoknya.

Berdasarkan permasalahan tersebut, dapat dikatakan bahwa proses dari pembelajaran matematika belum tercapai dengan baik. Tetapi hal tersebut bukan hanya semata-mata bahwa matematika itu sulit, melainkan disebabkan oleh beberapa faktor yang meliputi siswa itu sendiri, strategi dan model pembelajaran yang kurang tepat serta suasana didalam kelas yang menoton dan kurang menarik bagi siswa.

Dengan memperhatikan kondisi di atas perlu dikembangkan strategi atau model pembelajaran yang inovatif, yang dapat meningkatkan pemahaman konsep matematis siswa, daya kreatif dan keaktifan siswa. Salah satu model pembelajaran yang dapat meningkatkan pemahaman konsep siswa dan membuat siswa menjadi lebih aktif dan kreatif dalam proses pembelajaran di antaranya adalah dengan menggunakan model pembelajaran Quantum Teaching.

Model pembelajaran Quantum Teaching merupakan cara baru yang memudahkanproses pembelajaran, yang memadukan unsur seni dan pencapaian yang terarah, untuk segala mata 
pelajaran (Made Wena, 2013:160). Quantum Teaching merupakan model pembelajaran dengan menjadikan proses belajar menjadi lebih aktif, meriah dengan segala nuansanya. Quantum Teaching juga menyertakan segala kaitan, interaksi dan perbedaan yang memaksimalkan proses belajar. Model pembelajaran Quantum Teaching terdiri atas enam tahap yaitu Tumbuhkan, Alami, Namai, Demonstrasi, Ulangi dan Rayakan.Kemudian masing- masing tahap tersebut dapat diingat dalam bentuk akronim TANDUR (Bobby Deporter.dkk, 2010:31).

Penerapan pembelajaran dengan menggunakan model Quantum Teaching dilakukan dengan cara mengaitkan apa yang akan diajarkan guru dengan sebuah peristiwa, pikiran, perasaan yang diperoleh dari kehidupan rumah, sosial, atletik, musik, seni rekreasi atau akademis siswa. Hal tersebut membuat siswa tidak menghayal dalam membayangkan suatu konsep materi yang dipelajari.Sehingga siswa mampu mengungkapkan konsep matematikanya dengan bahasa yang benar dan mudah dipahami (Made Wena, 2013:161). Maka dari itu, dengan adanya hal tersebut kemampuan pemampuan konsep matematis siswa dapat dikembangkan dengan model pembelajaran Quantum Teaching.

Selain faktor proses pembelajaran di kelas, faktor lain yang mengakibatkan siswa dalam belajar dapat mengalami kesulitan adalah faktor intern. Faktor intern yakni seperti kesehatan, intelegensi, minat, bakat, motivasi, kematangan dan kesiapan(Muzakir dan Sutrisno, 1996: 155). Faktor-faktor tersebut terutama minat sangat penting dalam proses pemahaman konsep matematis.

Minat merupakan suatu kegiatan yang dilakukan oleh siswa secara tetap dalam melakukan proses belajar. Seseorang yang memiliki minat terhadap kegiatan tertentu cenderung memberikan perhatian yang besar terhadap kegiatan tersebut (Slameto, 2015: 180). Siswa yang memberikan perhatian yang besar terhadap pembelajaran akan mendukung keberhasilan siswa dalam menguasai materi pembelajaran.

Selain itu, minat juga penting dalam penerapan model pembelajaran Quantum Teaching karena didalam prosesnya model ini membutuhkan interaksi aktif dalam diskusi kelompok. Dengan minat belajar siswa, kelompok-kelompok yang terbentuk nantinya akan terdiri dari minat belajar matematika siswa yang heterogen.

Berdasarkan penjelasan tersebut dapat disimpulkan bahwa minat belajar diperlukan dalam kemampuan pemahaman konsep matematis dan penerapan model pembelajaran Quantum Teaching. Oleh karna itu, peneliti berkeinginan untuk melakukan penelitian dengan judul Pengaruh Penerapan Model Pembelajaran Quantum Teachingterhadap Pemahaman Konsep Matematis Berdasarkan Minat Belajar Matematika Siswa Sekolah Menengah Pertama Kampar.

\section{KEMAMPUAN PEMAHAMAN KONSEP MATEMATIS}

Pemahaman konsep matematis merupakan landasan penting untuk berfikir dan menyelesaikan permasalahan-permasalahan matematika maupun permasalahan dalam kehidupan sehari-hari.Pemahaman konsep juga merupakan salah satu tujuan dari setiap materi yang disampaikan oleh guru.

Pemahaman konsep adalah aspek kunci dari pembelajaran yang akan dipelajari. Demikian pula, pemahaman matematis merupakan landasan penting untuk berfikir dalam menyelesaikan persoalan-persoalan matematika maupun masalah kehidupan nyata. Selain itu, kemampuan matematis sangat mendukung pada pengembangan kemampuan matematis lainnya yaitu komunikasi, pemecahan masalah, koneksi, representasi, berfikir kritis,matematis serta kemampuan matematis lainnya. Pendapat serupa juga dikemukakan oleh Wiharno bahwa kemampuan pemahaman matematis merupakan suatu kekuantan yang harus diperhatikan selama proses pembelajaran matematika, terutama untuk memperoleh pengetahuan yang bermakna (Heris hendriana, Euis Eti Rohaeti, Utari Sumarmo, 2017: 3). 
Polya merinci kemampuan pemahaman pada empat tingkat, yaitu: (1)Pemahaman mekanikalyang dicirikan oleh kegiatan mengingat dan menerapkan rumus secara rutin dan mnghitung secara sederhana, (2) Pemahaman induktif: menerapkan rumus atau konsep dalam konsep dalam kasus sederhana atau dalam kasus serupa, (3) Pemahaman rasional: membuktikan kebenaran suatu rumus dan teorema, (4) Pemahaman intuitif: memperkirakan kebenaran dengan pasti (tanpa ragu-ragu) sebelum menganalisis lebih lanjut (Heris Hendrian dan Utari Soemarno, 2014:20).

Dalam penelitian ini peneliti mengambil beberapa indikator pemahaman konsep matematis berdasarkan Peraturan Dirjen Dikdasmen Nomor 506/C/Kep/PP/2004 yaitu: (1) Menyatakan ulang sebuah konsep, (2) Memberi contoh dan bukan contoh dari suatu konsep, (3) Menyajikan konsep dalam berbagai bentuk representasi matematis, (4)Menggunakan dan memanfaatkan serta memilih prosedur atau operasi tertentu, (5) Mengaplikasikan konsep atau algoritma pemecahan masalah (Heris hendriana, Euis Eti Rohaeti, Utari Sumarmo, 2017: 6).

\section{MODEL PEMBELAJARAN QUANTUM TEACHING}

Model pembelajaran Quantum Teaching adalah model pembelajaran dengan menjadikan proses belajar menjadi lebih aktif, meriah dengan segala nuansanya.Model Quantum Teaching juga menyertakan segala kaitan, interaksi dan perbedaan yang memaksimalkan momen belajar.Quantum Teaching mencangkuppetunjuk spesifik untuk menciptakan lingkungan belajar yang efektif, merancang kurikulum, menyampaikan isi, dan memudahkan proses belajar (Bobby Deporter.dkk, 2010: 31-33). Model pembelajaran Quantum Teaching merupakan cara baru yang memudahkan proses belajar, yang memadukan unsur seni dan pencapain yang terarah, untuk segala mata pelajaran(Made Wena, 2013:160).

Pembelajaran kuantum bersandar pada suatu konsep, yaitu "bawalah dunia siswa kedunia guru, dan antarkan dunia guru ke dunia siswa". Kegiatan ini dilakukan dengan cara mengaitkan apa yang akan diajarkan guru dengan sebuah peristiwa, pikiran, atau perasaan yang diperoleh dari kehidupan rumah, sosial, atletik, musik, seni rekreasi atau akademis siswa. Setelah kaitan itu terbentuk, siswa dapat dibawa kedunia guru, dan memberi siswa pemahaman tentang isi pembelajaran.Pada tahap ini rincian isi pembelajaran dijabarkan(Made Wena, 2013:161).

Model pembelajaran Quantum Teaching memiliki lima prinsip atau kebenaran tetap. Prinsipprinsip tersebut adalah: 1) segalanya berbicara, 2) segalanya bertujuan, 3) pengalaman sebelum pemberian nama, 4) akui setiap usaha, 5) jika layak dipelajari, maka layak pula dirayakan (Bobby Deporter.dkk, 2010: 36). Model pembelajaran Quantum Teaching mempunyai kerangka rencangan belajar yang dikenal dengan TANDUR: Tumbuhkan, Alami, Namai, Demonstrasikan, Ulang, dan Rayakan. Kerangka rancangan ini menjadi langkah-langkah dalam pembelajaran dengan menerapkan Model pembelajaran Quantum Teaching. Adapun langkah-langkah Model pembelajaran Quantum Teaching yaitu(Made Wena, 2013: 164-166):

1. Tumbuhkan

Tumbuhkan mengandung makna bahwa pada awal kegiatan pembelajaran pengajar harus menumbuhkan semangat siswa untuk belajar.

2. Alami

Alami mengandung makna bahwa proses pembelajaran akan lebih bermakna jika siswa mengalami secara langsung atau secara nyata materi yang diajarkan

3. Namai

Namai mengandung makna bahwa penamaan adalah saatnya untuk mengajarkan konsep, keterampilan berfikir, dan strategi belajar.Penamaan mampu memuaskan hasrat alami otak untuk memberi identitas, mengurutkan, dan mendefenisikan.

4. Demontrasi 
Demonstrasikan berarti bahwa memberi peluang pada siswa untuk menerjemahkan dan menerapkan pengetahuan mereka ke dalam pelajaran lain atau ke dalam kehidupan mereka.

5. Ulang

Ulang berarti bahwa proses pengulangan dalam kegiatan pembelajaran dapat memperkuat koneksi saraf dan menumbuhkan rasa ingin tahu atau yakin terhadap kemampuan siswa.

6. Rayakan

Rayakan berarti mengandung makna pemberian penghormatan pada siswa atas usaha, ketekunan, dan kesuksesannya. Dengan kata lain perayaan berarti pemberian umpan balik yang positif pada siswa atas keberhasilannya, baik berupa pujian, pemberian hadiah atau bentuk lainnya.

\section{MINAT BELAJAR MATEMATIKA}

Minat berasal dari bahasa dari bahasa latin " inter-est" yang berarti menghubungkan dua hal yang terpisah. Dalam perencanaan belajar, kita senantiasa menjumpai sesuatu yang terpisah yaitu peserta didik dan kurikulum. Sedangkan dalam proses belajar itu sendiri terdapat peserta didik dan perubahan tingkah laku yang diharapkan akan terjadi pada diri peserta didik. Sementara itu, minat secara istilah menurut Syah adalah kecenderungan dan kegairahan yang tinggi atau keinginan yang besar terhadap sesuatu (Taufik Tea, 2009:202).

Minat adalah suatu rasa suka dan rasa ketertarikan pada suatu hal atau aktivitas tanpa ada yang menyuruh (Slameto, 2015: 180). Minat pada dasarnya adalah penerimaan akan suatu hubungan antara diri sendiri dengan suatu di luar diri. Semakin kuat atau dekat hubungan tersebut semakin besar minat pada diri tersebut (Zalyana, 2014: 145).

Suatu minat dapat diekspresikan melalui suatu pernyataan yang menunjukkan bahwa siswa lebih menyukai suatu hal daripada hal lainnya, dapat pula dimanifestasikan melalui partisipasi dalam suatu aktivitas. Siswa yang memiliki minat terhadap suatu obyek tertentu cenderung untuk memberikan perhatian yang besar terhadap subjek tersebut (Slameto, 2015: 180).Pada dasarnya, minat sangat erat hubungannya dengan belajar. Karena itu minat belajar akan memberikan pengaruh terhadap kegiatan dan hasil belajar.

Minat belajar matematika adalah minat siswa terhadap pembelajaran matematika yang ditandai oleh perhatian siswa pada pembelajaran matematika, kesukaan siswa terhadap pembelajaran matematika, keinginan siswa untuk tahu lebih banyak mengenai matematika, tugastugas yang diselesaikan oleh siswa, motivasi siswa mempelajari matematika, kebutuhan siswa terhadap pembelajaran matematika dan ketekunan siswa dalam mempelajari matematika (Roida: 126). Berdasarkan uraian diatas maka minat belajar matematika adalah perasaan senang terhadap pelajaran matematika dimana seorang siswa menaruh perhatian yang besar terhadap matematika dan menjadikan matematika pelajaran yang mudah.Indikator dari minat belajar menurut Brown adalah: (1) Perasaan senang, (2) Keterlibatan dalam belajar, (3) Ketertarikan, (4) Perhatian, (5) Rajin dalam belajar dan rajin mengerjakan tugas, (6) Tekun dan disiplin dalam belajar, (7) Memiliki jadwal belajar(Heris hendriana, Euis Eti Rohaeti, Utari Sumarmo, 2017: 165).

\section{METODE PENELITIAN}

Jenis penelitian eksperimen yang digunakan adalah Quasi Eksperimental atau Eksperimen Semu, dimana variabel penelitian tidak memungkinkan untuk di kontrol sepenuhnya (Wina 
Sanjaya, 2013: 100). Desain yang digunakan adalah The Nonequivalent Pretest-Posttes Control Group Design(Karunia Eka dan Mokhammad Ridwan, 2017: 138). Populasi dalam penelitian ini adalah siswa Sekolah Menengah Pertama Kampar.Sampel yang diambil dalam penelitian ini terdiri dari dua kelas yaitu kelas eksperimen dan kelas kontrol yang dipilih dengan menggunakan teknik pengambilan sampel "Purposive Sampling”'Teknik Porposive Sampling merupakan teknik pengambilan sampel dengan pertimbangan tertentu (Karunia Eka dan Mokhammad Ridwan, 2017: 110). Dalam penelitian ini sampel diambil berdasarkan kesamaan guru yang mengajar matematika dan kesamaan jumlah siswa tiap kelasnya. Pengambilan sampel ini bermaksud agar dengan guru yang mengajar yang sama memungkinkan untuk kedua kelas mendapat perlakuan yang sama dalam proses pembelajaran. Dalam penelitian ini, peneliti mengambil kelas VIII-5 dan VIII-6 berdasarkan guru mengajar matematika yang sama dan jumlah siswa yang sama tiap kelasnya di Sekolah Menengah Pertama Negeri 2 Bangkinang Kota. Peneliti melakukan pretest, hasil dari pretest yaitu kedua sampel normal, homogen dan tidak memiliki perbedaan, sedangkan rata rata kelas memperlihatkan bahwa rata-rata kelas VIII 5 lebih rendah dari pada rata-rata kelas VIII 6. Karena rata-rata kelas VIII 5 lebih rendah maka peneliti menetapkan bahwa kelas VIII 5 sebagai kelas eksperimen dan kelas VIII 6 sebagai kelas kontrol.

Teknik pengumpulan data yang digunakan dalam penelitian ini adalah sebagai berikut:

\section{Teknis Tes}

Teknik pengumpulan data dengan memberikan tes adalah untuk memperoleh data kemampuan pemahaman konsep matematis siswa kelas eksperimen dan kelas kontrol baik sebelum (pretest) maupun sesudah (posttest) diterapkan model pembelajaran Quantum Teaching. Tes yang digunakan berbentuk uraian serta dirancang berdasarkan indikator kemampuan pemahaman konsep..

\section{Teknik Angket}

Teknik angket dilakukkan untuk memperoleh data minat belajar matematika siswa pada proses pembelajaran. Data minat belajar matematika yang dimaksud dalam penelitian ini berupa skor dari pernyataan-pernyataan yang menunjukkan perasaan senang, ketertarikan, perhatian, keterlibatan dalam belajar, rajin dalam belajar dan rajin mengerjakan tugas, tekun dan disiplin dalam belajar, serta memiliki jadwal belajar. Untuk memperlihatkan minat belajar matematika siswa digunakan skala likert dengan empat pilihan guna melihat kecenderungan pilihan siswa.

\section{Teknik Observasi}

Teknik observasi menggunakan alat atau instrumen observasi dilakukan peneliti untuk mengamati kegiatan peserta didik yang muncul ketika diberi perlakuan dengan model pembelajaran Quantum Teaching. Observasi juga dilaksanakan oleh seorang pengamat, yaitu guru mata pelajaran matematika di sekolah tersebut untuk mengamati kegiatan yang dilakukan peneliti dan peserta didik selama proses pembelajaran berlangsung.

\section{HASIL DAN PEMBAHASAN}

\section{Data Hasil Angket Minat Belajar Matematika Siswa}

Berdasarkan perhitungan yang telah dilakukan, diperoleh pengelompokan siswa dikelompokkan dengan kriteria tinggi, sedang, dan rendah berdasarkan hasil minat belajar matematika siswa sebagai berikut:

Tabel 1. Kriteria Pengelompokan Minat Belajar Matematika SISWA

\begin{tabular}{cc}
\hline Kriteria & Keterangan \\
\hline$x \geq 92,8181$ & Tinggi \\
$69,1819>x>92,8181$ & Sedang \\
$x \leq 69,1819$ & Rendah \\
\hline
\end{tabular}


Berdasarkan hasil pengelompokan minat belajar matematika siswa, diperoleh bahwa pada kelas eksperimen terdapat 5 siswa yang berminat belajar matematika tinggi, 11 siswa berminat belajar matematika sedang dan 5 siswa berminat belajar matematika rendah. Sedangkan pada kelas kontrol terdapat 4 siswa yang berminat belajar matematika tinggi, 12 siswa berminat belajar matematika sedang dan 5 siswa berminat belajar matematika rendah.

\section{Data Hasil Pretest}

Sebelum penelitian menerapkan model pembelajaran Quantum Teaching pada kelas eksperimen, lebih dahulu peneliti melakukkan pretest terhadap dua kelas yang dipilih.Analisis data test ini menggunakan uji t, yang mana sebelum dilakukan uji t terlebih dahulu dilakukan uji prasayarat yaitu data berdistribusi normal dan homogen. Perhatikan tabel dibawah ini:

Tabel 2. Uji Normalitas Pretest

\begin{tabular}{cccc}
\hline Kelas & $\boldsymbol{L}_{\text {hitung }}$ & $\boldsymbol{L}_{\text {tabel }}$ & Kriteria \\
\hline Eksperimen & 0,1034 & 0,190 & Normal \\
Kontrol & 0,1343 & 0,190 & Normal \\
\hline
\end{tabular}

Tabel 3. Uji Homogenitas Pretest

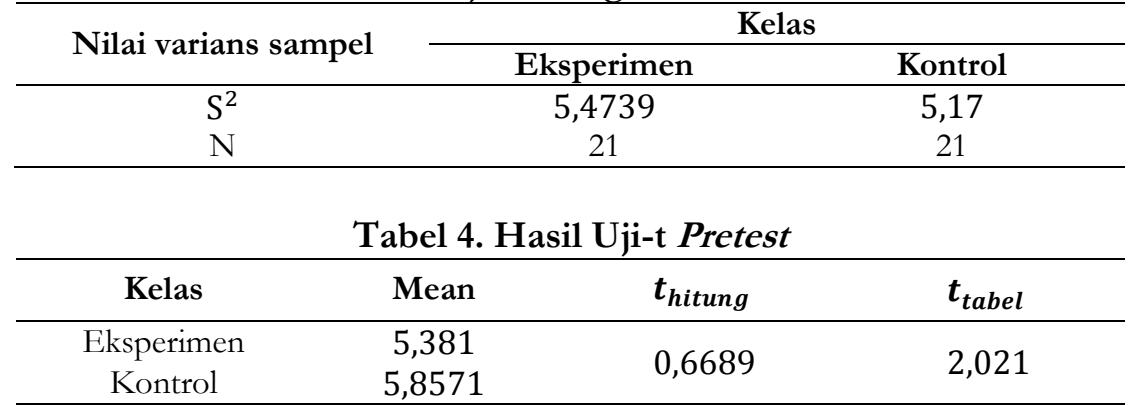

Berdasarkan perhitungan dengan menggunakan uji-t diperoleh $t_{\text {hitung }}<t_{\text {tabeel }}$. Sehingga dapat disimpulkan bahwa, dua kelompok sampel yang dipilih tidak terdapat perbedaan kemampuan awal pemahaman konsep matematis antara kelas kelas eksperimen kelas kontrol yang signifikan, artinya kedua kelompok tersebut dapat digunakan dalam penelitian

\section{Data Hasil Posttest}

Analisis data test ini menggunakan uji $\mathrm{t}$, yang mana sebelum dilakukan uji t terlebih dahulu dilakukan uji prasayarat yaitu data berdistribusi normal dan homogen.

1. Hipotesis Pertama

Tabel 5. Uji Normalitas Posttest

\begin{tabular}{cccc}
\hline Kelas & $\boldsymbol{L}_{\text {hitung }}$ & $\boldsymbol{L}_{\text {tabel }}$ & Kriteria \\
\hline Eksperimen & 0,1562 & 0,190 & Normal \\
Kontrol & 0,157 & 0,190 & Normal \\
\hline
\end{tabular}

TABEL 6. UJI HOMOGENITAS POSTTEST

\begin{tabular}{ccc}
\hline \multirow{2}{*}{ Nilai varians sampel } & \multicolumn{2}{c}{ Kelas } \\
\cline { 2 - 3 } & Eksperimen & Kontrol \\
\hline $\mathrm{S}^{2}$ & 9,7415 & 18,1406 \\
$\mathrm{~N}$ & 21 & 21 \\
\hline
\end{tabular}

Tabel 7. Hasil Uji-t Posttest

\begin{tabular}{ccc}
\hline $\mathbf{t}_{\text {hitung }}$ & $\mathbf{t}_{\text {tabel }}$ & Keterangan \\
\hline 3,3888 & 2,021 & $\mathrm{H}_{\mathrm{a}}$ diterima \\
\hline
\end{tabular}

Dengan taraf signifikan 5\%atau 0,05, maka diperoleh $t_{\text {tabel }}=2,021$. Dengan $t_{\text {hitung }}=3,3888$ berarti $t_{\text {hitung }}>t_{\text {tabel }}$ yaitu $3,3888>2,021$, maka $H_{o}$ ditolak dan 
$\mathrm{H}_{\mathrm{a}}$ diterima. Sehingga dapat disimpulkan, terdapat perbedaan kemampuan pemahaman konsep matematis antara siswa yang mengikuti pembelajaran dengan model Quantum Teachingdengan siswa yang mengikuti pembelajaran yang diterapkan guru.

2. Hipotesis Kedua

Tabel 8. Uji Normalitas Posttest Berminat Belajar Matematika Kelompok Tinggi

\begin{tabular}{cccc}
\hline Kelas & $\boldsymbol{L}_{\text {hitung }}$ & $\boldsymbol{L}_{\text {tabel }}$ & Kriteria \\
\hline Eksperimen & 0,2888 & 0,337 & Normal \\
Kontrol & 0,3315 & 0,381 & Normal \\
\hline
\end{tabular}

Tabe1 9. Uji Homogenitas Posttest Berminat Belajar Matematika Kelompok Tinggi

\begin{tabular}{ccc}
\hline \multirow{2}{*}{ Nilai varians sampel } & \multicolumn{2}{c}{ Kelas } \\
\cline { 2 - 3 } & Eksperimen & Kontrol \\
\hline $\mathrm{S}^{2}$ & 0,24 & 1,6875 \\
$\mathrm{~N}$ & 21 & 21 \\
\hline
\end{tabular}

Tabel 10. Hasil Uji-t' Posttest Berminat Belajar Matematika Kelompok Tinggi

\begin{tabular}{ccc}
\hline $\mathbf{t}_{\text {hitung }}$ & $\mathbf{t}_{\text {tabel }}$ & Keterangan \\
\hline 3,4283 & 2,365 & $\mathrm{H}_{\mathrm{a}}$ diterima \\
\hline
\end{tabular}

Dengan taraf signifikan 5\%atau 0,05, maka diperoleh $t_{\text {tabel }}=2,365$. Dengan $t_{\text {hitung }}=3,4283$ berarti $t_{\text {hitung }}>t_{\text {tabel }}$ yaitu 3,4283 $>2,365$, maka $\mathrm{H}_{\mathrm{o}}$ ditolak dan $\mathrm{H}_{\mathrm{a}}$ diterima. Sehingga dapat disimpulkan, terdapat perbedaan kemampuan pemahaman konsep matematis antara siswa berminat belajar tinggi yang belajar mengikuti pembelajaran dengan model Quantum Teachingdengan siswa berminat belajar tinggi yang belajar mengikuti pembelajaran yang diterapkan guru.

3. Hipotesis ketiga

Tabel 11. Uji Normalitas Posttest Berminat Belajar Matematika Kelompok Sedang

\begin{tabular}{cccc}
\hline Kelas & $\boldsymbol{L}_{\text {hitung }}$ & $\boldsymbol{L}_{\text {tabel }}$ & Kriteria \\
\hline Eksperimen & 0,181 & 0,249 & Normal \\
Kontrol & 0,1457 & 0,242 & Normal \\
\hline
\end{tabular}

Tabel 12. Uji Homogenitas Posttest Berminat Belajar Matematika Kelompok Sedang

\begin{tabular}{ccc}
\hline \multirow{2}{*}{ Nilai varians sampel } & \multicolumn{2}{c}{ Kelas } \\
& Eksperimen & Kontrol \\
\hline$S^{2}$ & 3,1405 & 15,5764 \\
$\mathrm{~N}$ & 21 & 21 \\
\hline
\end{tabular}

Tabel 13. Hasil uji-t' Posttest Berminat Belajar Matematika Kelompok Sedang

\begin{tabular}{ccc}
\hline $\mathbf{t}_{\text {hitung }}$ & $\mathbf{t}_{\text {tabel }}$ & Keterangan \\
\hline 3,1365 & 2,080 & $\mathrm{H}_{\mathrm{a}}$ diterima \\
\hline
\end{tabular}

Dengan taraf signifikan 5\%atau 0,05, maka diperoleh $t_{\text {tabel }}=2,080$. Dengan $t_{\text {hitung }}=3,1365$ berarti $t_{\text {hitung }}>t_{\text {tabel }}$ yaitu 3,1365 $>2,080$, maka $\mathrm{H}_{\mathrm{o}}$ ditolak dan $\mathrm{H}_{\mathrm{a}}$ diterima. Sehingga dapat disimpulkan, terdapat perbedaan kemampuan pemahaman konsep matematis antara siswa berminat belajar sedang yang belajar mengikuti pembelajaran dengan model Quantum Teachingdengan siswa berminat belajar sedang yang belajar mengikuti pembelajaran yang diterapkan guru.

4. Hipotesis Keempat 
Tabel 14. Uji Normalitas Posttest Berminat Belajar Matematika Kelompok Rendah

\begin{tabular}{cccc}
\hline Kelas & $\boldsymbol{L}_{\text {hitung }}$ & $\boldsymbol{L}_{\text {tabel }}$ & Kriteria \\
\hline Eksperimen & 0,2888 & 0,337 & Normal \\
Kontrol & 0,3085 & 0,337 & Normal \\
\hline
\end{tabular}

Tabel 15. Uji Homogenitas Posttest Berminat Belajar Matematika Kelompok Rendah

\begin{tabular}{ccc}
\hline \multirow{2}{*}{ Nilai varians sampel } & \multicolumn{2}{c}{ Kelas } \\
\cline { 2 - 3 } & Eksperimen & Kontrol \\
\hline $\mathrm{S}^{2}$ & 10,8 & 1,44 \\
$\mathrm{~N}$ & 21 & 21 \\
\hline
\end{tabular}

Tabel 16. Hasil Uji-t' Posttest Berminat Belajar Matematika Kelompok Rendah

\begin{tabular}{ccc}
\hline $\mathbf{t}_{\text {hitung }}$ & $\mathbf{t}_{\text {tabel }}$ & Keterangan \\
\hline 2,3116 & 2,306 & $\mathrm{H}_{\mathrm{a}}$ diterima \\
\hline
\end{tabular}

Dengan taraf signifikan 5\%atau 0,05, maka diperoleh $t_{\text {tabel }}=2,306$. Dengan $t_{\text {hitung }}=2,3116$ berarti $t_{\text {hitung }}>t_{\text {tabel }}$ yaitu 2,3116 $>2,306$, maka $\mathrm{H}_{\mathrm{o}}$ ditolak dan $\mathrm{H}_{\mathrm{a}}$ diterima. Sehingga dapat disimpulkan, terdapat perbedaan kemampuan pemahaman konsep matematis antara siswa berminat belajar rendah yang belajar mengikuti pembelajaran dengan model Quantum Teachingdengan siswa berminat belajar rendah yang belajar mengikuti pembelajaran yang diterapkan guru.

\section{PENUTUP}

\section{Kesimpulan}

1. Terdapat perbedaan kemampuan pemahaman konsep matematisantara siswa yang mengikuti pembelajaran dengan model Quantum Teachingdengan siswa yang mengikuti pembelajaran yang diterapkan guru.

2. Terdapat perbedaan kemampuan pemahaman konsep matematis antara siswa berminat belajar tinggi yang belajar mengikuti pembelajaran dengan model Quantum Teachingdengan siswa berminat belajar tinggi yang belajar mengikuti pembelajaran yang diterapkan guru.

3. Terdapat perbedaan kemampuan pemahaman konsep matematis antara siswa berminat belajar sedang yang belajar mengikuti pembelajaran dengan model Quantum Teachingdengan siswa berminat belajar sedang yang belajar mengikuti pembelajaran yang diterapkan guru.

4. Terdapat terdapat perbedaan kemampuan pemahaman konsep matematis antara siswa berminat belajar rendah yang belajar mengikuti pembelajaran dengan model Quantum Teachingdengan siswa berminat belajar rendah yang belajar mengikuti pembelajaran yang diterapkan guru.

Berdasarkan hasil tersebut dapat menjawab dari judul yang diangkat oleh peneliti yaitu Pengaruh Penerapan Model Pembelajaran Quantum Teachingterhadap Pemahaman Konsep Matematis Berdasarkan Minat Belajar Matematika Siswa Sekolah MenengahPertama Kampar.

\section{Saran}

Berdasarkan hasil penelitian ini, peneliti memberikan saran :

1. Diharapkan kepada guru matematika untuk menjadikan model pembelajaran Quantum Teaching sebagai salah satu model pembelajaran untuk meningkatkan kemampuan pemahaman konsep matematis siswa.

2. Penelitian ini dilakukan terhadap siswa SMP Negeri 2 Bangkinang Kota. Oleh karena itu, peneliti menyarankan untuk diterapkan di SMP lainnya. 
3. Bagi peneliti selanjutnya agar dapat mengukur kemampuan matematika yang lain dengan model pembelajaran yang sama.

\section{REFERENSI}

Eka, Karunia, dkk. 2017. Penelitian Pendidikan Matematika. PT. Refika Aditama: Bandung

Fitria Rozi. 2009. Penilaian Berbasis Kelas (Classroom Assesment) dalam Pembelajaran Matematika. Pekanbaru

Hendriana, Heris, dkk. 2014. Penilaian Pembelajaran Matematika. PT. Rafika Aditama: Bandung

Hendriana, Heris, dkk. 2017. Hard skills dan Soft Skills Matematik. Siswa. P'T Refika Aditama: Bandung

Sanjaya, Wina. 2013. Penelitian Pendidikan: Jenis, Metode, Prosedur. Kencana: Jakarta

Tea Taufik. 2009. Inspiring Teaching. Jakarta: Gema Insani

Wena Made. 2013. Strategi Pembelajaran Inovatif Kontenporer. Jakarta: PT Bumi Aksara

Zalyana. 2014. Psikologi Pembelajaran. Pekanbaru: Cv Mutiara Pesisir Sumatra

Slameto.2015.Belajar dan Faktor Yang Mempengarubi. Jakarta: PT. Rineka Cipta

Deporter Bobby, dkk. 2010. Quantum Teaching: Mempraktekekan Quantum Learning Di Ruang-Ruang Kelas. Bandung: PT Mizan Pustaka

Muzakir dan Sutrisno.1996. Psikologi Pendidikan. Semarang. Pustaka Setia 